\title{
Research on the Construction of College English Reading Teaching System Based on the "Internet+" Environment
}

\section{Qing Xu}

Wuhan Polytechnic University WUhan City, Hubei Province, 430023, People's Republic of China

\begin{abstract}
College English teaching is of great significance to the improvement of students' English proficiency and the cultivation of English application ability, especially reading teaching can effectively improve college students' oral, comprehension and writing skills. However, many college students have the problem of weak enthusiasm when learning English reading. At this time, efficient English reading teaching should effectively use Internet technology to reconstruct the reading teaching system, optimize the quality of English reading teaching, and provide reading teaching attractive to students.

Keywords: Internet; College English Reading; Teaching System Construction

In the English system, reading teaching is a very important link. On the one hand, it can deepen students' mastery of English and exercise their oral English so that students can truly communicate in English. On the other hand, it can lead students to understand English culture., It also promotes the English writing ability of college students, and can improve students' English proficiency as a whole. In the Internet + environment, colleges and universities should learn to use Internet technology to optimize the construction of an English reading teaching system, enrich reading teaching resources, and improve the quality of reading teaching.
\end{abstract}

\section{Change the English teaching system}

At present, the main problems of English teaching in my country's colleges and universities are the single teaching form and the boring teaching content, which directly leads to the failure of good teaching results in English reading teaching. The solution of these problems requires reform and innovation of the English teaching system. While continuing to improve their teaching ability, college English teachers must also devote more energy to teaching reform. First, reform the teaching materials to control the difficulty of the teaching materials based on the actual situation of the students, pay attention to the knowledge points that are generally difficult for students to understand, and especially control the teaching materials of reading teaching. Only when students feel the strength of the school's reform of the English teaching system, can they increase their attention to English learning and stimulate their love for English reading learning, thereby improving their English reading ability and English application ability.

\section{Use inquiry learning to achieve personalized reading}

The key of English reading teaching is to guide students to form good English reading habits, thereby improving students' understanding of English knowledge. The formation of English reading habit needs to be accumulated over time and gradually. In the context of the Internet + , more and more English reading platforms are pouring into the market. In such platforms, students can perform progressive reading exercises according to the amount of thinking, knowledge reserves, and difficulty level, and will receive them as soon as they are completed. Positive feedback from the platform can improve students' reading experience and self-confidence in learning, thereby fostering students'

Copyright $\odot 2020$ Qing Xu

doi: $10.18282 /$ le.v9i7.1496

This is an open-access article distributed under the terms of the Creative Commons Attribution Non-Commercial License

(http://creativecommons.org/licenses/by-nc/4.0/), which permits unrestricted non-commercial use, distribution, and reproduction in any medium, provided the original work is properly cited. 
reading habits. In the process of cultivating reading habits, teachers should pay attention to individual reading, because language acquisition is a relatively complex mental activity. It is not only affected by intellectual factors, but also by non-intellectual factors such as memory, personality and anxiety. Therefore, English teachers should respect the individual differences of college students when teaching reading, and teach students of different levels in accordance with their aptitude. When students have accumulated a certain amount of reading, teachers can use inquiry-based learning to guide students from reading enthusiasm to reading habits, so that students can form a psychological appeal for reading, and then they can learn to read independently.

\section{Use fresh texts to mobilize reading interest}

The improvement of students' learning enthusiasm requires interest as the driving force. When students' interest level reaches a certain height, it will be transformed into learning enthusiasm and learning enthusiasm. Under the guidance of learning enthusiasm, students will have more abundant reading experience and can get better Reading learning effect.

In the past, English reading texts did not pay enough attention to the students' individual language ability and thinking ability, so there was some neglect of the students' interest level. For individuals, a unified text could hardly make the students' cognitive level fast. Promotion is a reality that traditional education must accept. However, with the continuous development of the Internet, more and more online English reading platforms have emerged. The text sources of these platforms are very cutting-edge and interesting, and they are updated daily. They are very highlevel spot texts. Adapt to different English abilities, and have strong authenticity, avoiding the problem of fictitious content in the past reading text. Such texts can not only satisfy students' curiosity about new things, but also stimulate students' motivation in English reading. Students can use the process of English reading to obtain information from the outside world, broaden their horizons, and mobilize English reading. Enthusiasm, and more importantly, long-term accumulation can increase students' reading volume, improve the memory of important words and languages from an objective degree, avoid students losing interest in learning due to boring grammatical analysis, and promote students' text information processing Increased ability.

\section{Innovative teaching mode to cultivate reading ability}

In order to truly improve the reading ability of students, teachers must adapt to the current situation and innovate the teaching mode. The cooperative learning method in college English reading education is a very effective teaching method, which is not only conducive to creating a good learning atmosphere and inspiring students Reading interest, and more importantly, cultivates the tacit cooperation between students in the process of cooperative learning, and enhances mutual friendship. Cooperative learning needs to divide the class students into different groups. After the teaching tasks are released, the group members will discuss and research among themselves, and complete the tasks in the process of joint collaboration. In the traditional teaching methods in the past, the design of English reading textbooks often only raised questions about reading text. Try it on the Internet. The content covered by the reading text is more profound. In addition to education-related content, it pays more attention to the students' relationship. Cooperative communication, which transforms individual learning in the traditional sense into multi-person learning, and uses cooperative communication to complete a new reading mode. Under the optimization of the new multimedia technology, the cooperative learning method has realized a close integration between reading teaching and background. More and more students have begun to actively participate in reading learning, actively improve reading literacy, and have more and more confidence in reading courses.

\section{Concluding remarks}

All in all, for Chinese college students, if they want to improve their English reading ability, teachers and students need to work together. Teachers must reform their own teaching concepts and cultivate students' autonomous learning ability through innovative teaching methods. Students must take the initiative The fun of English learning, construct 
a brand-new English reading teaching system, fully utilize the advantages of the Internet, and promote the continuous improvement of English proficiency.

\section{References}

1. Zhou Shanshan. Research on the construction of college English reading teaching system based on the "Internet +" environment [J]. Journal of Heilongjiang Teachers Development College, 2020, 39(10): 135-137.

2. Zhang Lei. Research on the Construction of College English Reading Teaching System Based on the "Internet+" Environment—Comment on "Multicultural and Contemporary English Teaching" [J]. Forest Products Industry, 2020, 57(07): 113 .

3. Guo Jingjing. Research on the Construction of College English Reading Teaching System in the "Internet+" Environment[J]. Journal of Pu'er University, 2019, 35(06): 105-106.

4. Gou Xiaoliang. Research on the construction of a higher vocational business English reading teaching system based on the "Internet +" environment[J]. Journal of Jiamusi Vocational College, 2019(09):144-145. 